\title{
PENGARUH PEMBERIAN KOMBINASI NAC DENGAN VITAMIN C DAN E TERHADAP STRES OKSIDATIF PADA HUVECs DIPAPAR PLASMA EKLAMPSIA
}

\author{
THE INFLUENCE OF THE COMBINATION OF NAC WITH VITAMIN C AND E TO \\ OXIDATIVE STRESS ON HUVECS EXPOSED WITH ECLAMPSIA PLASMA
}

\author{
Siti Candra Windu Baktiyani \\ Laboratorium Obstetri \& Ginekologi Fakultas Kedokteran Universitas Brawijaya/ RS dr. Saiful Anwar Malang
}

\begin{abstract}
The blood plasma of preeclampsia contains oxidative stress factors. The oxidative stress is predicted as the cause of disfunction and destruction of endothelial cell which will influence the severity of Preeclampsia and Eclampsia complications. Previous research showed that the treatment of antioxidant on preeclamsia was still controvertion. The objectives of this research is to investigate the influence of the combination of NAC and vitamin $C$ or vitamin $E$ or both of them on the level of $\mathrm{H}_{2} \mathrm{O}_{2}, \mathrm{MDA}$, NO and GSH/GSSG ratio of endothelial cell culture exposed with Eclampsia plasma. The method was an experimental study using HUVECs exposed with to $2 \%$ plasma Eclampsia as an Eclampsia model invitro. The HUVECs were than treated with NAC $2 \mu M$ only (group 1), NAC $2 \mu M+$ vitamin C $100 \mu M$ (group 2), NAC $2 \mu M+$ vitamin E 100 $\mu M$ (group 3), and NAC $2 \mu M+$ vitamin C $100 \mu M+$ vitamin E $100 \mu M$ (group 4) for 24 hours. The parameter measured in this study were $\mathrm{H}_{2} \mathrm{O}_{2}, M D A$, NO and GSH/GSSG ratio. Result showed that $\mathrm{H}_{2} \mathrm{O}_{2}, \mathrm{MDA}$, and NO concentration are unsignificantly different among treatment groups although there was a decreasing on group treated with combination of NAC, vitamin C and Vitamin E. GSH/GSSG ratio is significantly higher on the groups treated with NAC $2 \mu M+$ vitamin $C$ $100 \mu \mathrm{M}$ or NAC $2 \mu \mathrm{M}+$ vitamin C $100 \mu \mathrm{M}+$ vitamin $E 100 \mu \mathrm{M}$ compared to addition of NAC $2 \mu M$ or NAC $2 \mu M+$ vitamin $E 100 \mu \mathrm{M}$ (p<0.05). It can be concluded that the combination of antioxidant NAC $2 \mu \mathrm{M}+$ vitamin $C 100 \mu \mathrm{M}$ or NAC $2 \mu \mathrm{M}$ + vitamin C $100 \mu \mathrm{M}$ + vitamin E $100 \mu \mathrm{M}$ more optimal in increasing GSH/GSSG ratio.

Key words: HUVECs, Eclampsia plasma, Oxidative stress, Antioxidant
\end{abstract}

\section{PENDAHULUAN}

Preeklampsia merupakan keadaan patologis yang spesifik pada kehamilan manusia (1). Angka kejadian preeklampsia berkisar antara $7-10 \%$ dari seluruh kehamilan (2), kejadian eklampsia di Rumah Sakit Parkland Amerika Serikat berkisar 0,03 \%- 0,043\% dari 3250 persalinan (3). Kejadian preeklampsia di Rumah Sakit Dr. Saiful Anwar Malang sekitar 7-12\%, sedangkan kejadian eklampsia berkisar 0,81-1,08\%(4).

Patomekanisme terjadinya pre-eklampsia sampai sekarang masih merupakan disease of theories. Preeklampsia disebabkan oleh pengurangan perfusi uteroplasental. Dijelaskan bahwa pengurangan perfusi uteroplasental disebabkan oleh 1) penyakit vaskuler pada maternal. 2) plasentasi abnormal dipengaruhi faktor genetik, imunologi dan inflamasi. 3) Excessive trophoblast (3). Pengurangan perfusi uteroplasental menyebabkan terjadinya kelainan iskemia - reperfusi pada plasenta akan

Jurnal Kedokteran Brawijaya, Vol. XXIII, No.3, Desember 2007 Korespondensi: Siti Candra Windu Baktiyani, Laboratorium Obstetri Ginekologi Fakultas Kedokteran Universitas Brawijaya Malang, Telp: (0341) 569117 HP: 08125289348 menghasilkan spesies oksigen reaktif yang ditransfer ke sirkulasi maternal (5). Spesies oksigen reaktif (SOR) yaitu superokside $\left(\mathrm{O}_{2} \bullet\right)$, radikal hidrosil $(\mathrm{OH} \cdot)$, hidrogen peroksida $\left(\mathrm{H}_{2} \mathrm{O}_{2}\right)$ pada sirkulasi maternal akan meningkatkan aktivasi neutrophil yang ditunjukkan dengan peningkatan neutrophil elastase. Aktivasi neutrophil akan melepaskan SOR yang menyebabkan lipid peroksidasi di membran sel, lisis sel endotel, reaktivitas vaskuler dan peningkatan permiabilitas vaskuler (6).

Pada penelitian pendahuluan didapatkan kadar vitamin $\mathrm{C}$, vitamin $\mathrm{B} 1$, vitamin $\mathrm{A}$ dan $\mathrm{Fe}$ dengan metode recall diet asupan makanan pada ibu yang mengalami preeklampsia berat dan eklampsia lebih rendah secara signifikan dibandingkan dengan asupan makanan dari ibu kehamilan normal (7). Keadaan ini diduga berhubungan dengan peningkatan parameter $\mathrm{H}_{2} \mathrm{O}_{2}$, $\mathrm{NO}$ (Nitric oxide), MDA (Molunedialdehyde) dan penurunan rasio GSH/GSSG (Glutation tereduksi/teroksidasi) yang menggambarkan keadaan stress oksidatif pada penderita preeklampsia. Dengan kurangnya asupan antioksidan yang berasal dari diet menyokong memberatnya preeklampsia, karena antioksidan semakin tidak cukup untuk menetralisir oksidan yang semakin meningkat seiring dengan meningkatnya usia kehamilan (8). 
Penelitian selanjutnya dengan memaparkan plasma Kehamilan Normal, preeklamsia berat dan eklamsia HUVECs menunjukkan bahwa apabila plasma dari kehamilan preeklampsia berat dan eklampsia menyebabkan peningkatan oksidan $\mathrm{H}_{2} \mathrm{O}_{2}, \mathrm{MDA}$, NO dan penurunan kadar rasio GSH/GSSG. Hal ini menggambarkan plasma dari preeklampsia berat dan eklampsia sitotoksik terhadap sel endotel dan menyebabkan keadaan stress oksidatif pada HUVECs (4).

Stress oksidatif akan menyebabkan disfungsi sel endotel yang merupakan gambaran sentral dalam patogenesis preeklampsia (9). Stress oksidatif yang ada pada penderita preeklampsia perlu dikontrol dengan pemberian antioksidan dari luar (10). Antioksidan mempunyai 2 sifat yaitu larut dalam lemak dan larut dalam air. Glutathion dan vitamin $C$ bersifat larut dalam air dan vitamin $\mathrm{E}$ bersifat larut dalam lemak. Tempat bekerjanya masing - masing antioksidan berbeda - beda. Antioksidan NAC disamping bertindak sebagai antioksidan sendiri, juga sebagai prekursor pembentukan GSH. Antioksidan GSH bekerja di sitosol, mitokondria dan nukleus (11). Sedangkan antioksidan vitamin $\mathrm{E}$ bekerja di membran sel dan vitamin $\mathrm{C}$ bekerja di sitosol dan di ekstrasel (12). Penelitian klinis yang pernah dilakukan dengan pemberian Vitamin E 100$300 \mathrm{mg} / \mathrm{hari}$ pada penderita preeklampsia tidak ada pengaruhnya pada tekanan darah darah dan proteinuri. Sedangkan pada pemberian kombinasi vitamin $\mathrm{C}$ dengan vitamin E pada ibu hamil di awal kehamilan secara randomisasi, dapat mencegah terjadinya preeklampsia (13).

Dengan pemberian 2 macam antioksidan dapat mencegah terjadinya preeklampsia. Oleh karena itu pada penelitian ini mencoba dengan memakai 3 macam antioksidan untuk mengetahui perubahan yang terjadi apabila NAC $2 \mu \mathrm{M}$ dikombinasi dengan vitamin C $100 \mu \mathrm{M}$ dan Vitamin E $100 \mu \mathrm{M}$ pada kultur sel endotel (HUVECs) yang dipapar plasma $\mathrm{E}$.

\section{METODE}

Penelitian dilakukan di laboratorium Biomedik Fakultas Kedokteran Universitas Brawijaya. Penelitian ini merupakan penelitian eksperimental dengan menggunakan HUVECs yang dipapar dengan $2 \%$ plasma kehamilan normal (kontrol negatif), dipapar dengan $2 \%$ plasma eklampsia sebagai model eklampsia in vitro (kontrol positip), setelah itu dilakukan penambahan paparan NAC $2 \mu \mathrm{M}$ (perlakuan 1), $\mathrm{NAC} 2 \mu \mathrm{M}+$ Vitamin C $100 \mu \mathrm{M}$ (perlakuan 2), NAC $2 \mu \mathrm{M}+$ Vitamin E $100 \mu \mathrm{M}$ (perlakuan 3), dan NAC $2 \mu \mathrm{M}+$ Vitamin C $100 \mu \mathrm{M}+$ Vitamin E $100 \mu \mathrm{M}$ (perlakuan 4). Inkubasi dilakukan selama 24 jam, kemudian dilakukan pemeriksaan $\mathrm{H}_{2} \mathrm{O}_{2}, \mathrm{MDA}$, NO dan rasio GSH/GSSG. Analisa statistik menggunakan SPSS 14, dilakukan uji beda One Way
Anova dengan tingkat kepercayaan 95\%, kemudian untuk mengetahui pemaparan mana yang menunjukkan perbedaan ditunjukkan dengan uji BNT dengan tingkat kepercayaan $95 \%$.

\section{Metode pemeriksaan $\mathrm{H}_{2} \mathrm{O}_{2}$ \\ (NWLSS ${ }^{\text {TM }}$ Hydrogen Peroxide Assay): (14)}

Pengukuran kadar $\mathrm{H}_{2} \mathrm{O}_{2}$ dilakukan pada medium kultur sel endotel HUVECs. Sebanyak $5 \mu \mathrm{L}$ deionozed water diletakkan pada setiap sumur dalam microplate 96, kemudian ditambahkan $20 \mu \mathrm{L}$ medium kultur. Plate digoyang-goyang selama 5 menit pada suhu ruangan. Setelah itu ditambahkan $200 \mu \mathrm{L}$ larutan Working XO:Fe pada setiap sumur. Diinkubasi selama 45 menit. Dibaca dengan micrplate reader pada panjang gelombang $560 \mathrm{~nm}$.

\section{Pemeriksaan MDA pada kultur sel endotel (HUVECs):}

\section{(15)}

Kultur sel endotel diberi cairan yang mengandung 15\% w/v trichloroacetic acid, 0,375 w/v thiobarbituric acid, 0,25 hydrichloric acid dan $0,2 \%$ triton $X$. Selanjutnya sel dikerok dan disuspensi dengan pemanasan $100^{\circ} \mathrm{C}$ selama 15 menit lalu disentrifugasi pada $4500 \mathrm{rpm}$ selama 10 menit. Supernatan diukur dengan spektrofometer pada panjang gelombang $532 \mathrm{~nm}$.

\section{Pemeriksaan Nitrit ( NWLSS ${ }^{\mathrm{TM}}$ Nitric Oxide Assay): (16)}

Lima puluh mikroliter sampel ditambah $50 \mu \mathrm{L}$ reduction buffer, kemudian ditambah $50 \mu \mathrm{L}$ Griess reagent $A$ dan terakhir ditambah $50 \mu \mathrm{L}$ griess reagent B. Diinkubasi 20 menit pada suhu ruang. Dibaca dengan microplate reader pada panjang gelombang $540 \mathrm{~nm}$.

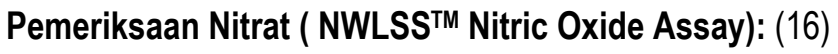

Sebanyak $60 \mu \mathrm{L}$ sampel dimasukkan ke $C D$ beat yang telah bersih. Ditambahkan $60 \mu \mathrm{L}$ ZnSO4, kemudian divortek. Ditambah $75 \mu \mathrm{L} \mathrm{NaOH}$ divortek lagi. Disentrifuse 3000 rpm selama 5 menit. Supernatan diambil untuk diperiksa kadar nitrat. Diambil 100 $\mu \mathrm{L}$ sampel $+100 \mu \mathrm{L}$ reduction bufffer, kemudian divortek lagi. Ditambah $50 \mu \mathrm{L}$ Griess reagent A dan $50 \mu \mathrm{L}$ Griess reagent B. Diinkubasi 20 menit . Dibaca dengan microplate reader pada panjang gelombang $540 \mathrm{~nm}$.

\section{Pemeriksaan Rasio GSH/GSSH : (17)}

Lima puluh mikroliter sampel dan standart dipipet serta dimasukkan pada setiap sumuran, kemudian ditambahkan 100uL reaction mixture (GSH : Mix $5 \mathrm{ml}$ of DNTB, $5 \mathrm{ml}$ of $\mathrm{NADPH}, 5.75 \mathrm{ml}$ of buffer and $0.1 \mathrm{ml}$ of $\mathrm{GSH}$ reductase; GSSH : Mix $5 \mathrm{ml}$ of DNTB, $5 \mathrm{ml}$ of NADPH, $5.75 \mathrm{ml}$ of buffer). Dibaca dengan microplate reader pada panjang gelombang $405 \mathrm{~nm}$. 


\section{HASIL PENELITIAN}

\section{Kadar $\mathrm{H}_{2} \mathrm{O}_{2}$ pada Media HUVECs}

Kadar $\mathrm{H}_{2} \mathrm{O}_{2}$ medium kultur HUVECs yang dipapar dengan $2 \%$ plasma kehamilan normal (kontrol negatif), dipapar dengan $2 \%$ plasma eklampsia sebagai model eklampsia in vitro (kontrol positip), dilakukan penambahan paparan NAC $2 \mu \mathrm{M}$ (perlakuan 1), NAC $2 \mu \mathrm{M}+$ Vitamin C $100 \mu \mathrm{M}$ (perlakuan 2), NAC $2 \mu \mathrm{M}+$ Vitamin $\mathrm{E} 100 \mu \mathrm{M}$ (perlakuan 3), dan NAC $2 \mu \mathrm{M}+$ Vitamin C $100 \mu \mathrm{M}+$ Vitamin E 100 $\mu \mathrm{M}$ (perlakuan 4) dapat dilihat pada gambar 1.

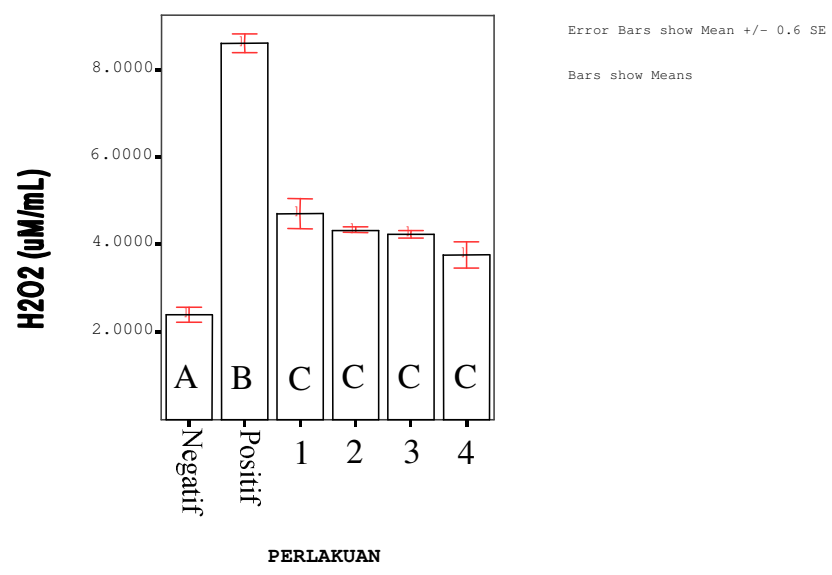

Gambar 1. Grafik kadar rata-rata $\pm \mathrm{SE} \mathrm{H}_{2} \mathrm{O}_{2}$ pada media kultur HUVECs semua kelompok.

Keterangan : ${ }^{*}=$ signifikan $(p<0.05)$

Notasi yang berbeda menunjukkan perbedaan yang signifikan.

- = HUVECs dipapar dengan $2 \%$ plasma kehamilan normal

$+=$ HUVECs dipapar dengan $2 \%$ plasma eklampsia

1. = HUVECs dipapar dengan $2 \%$ plasma eklampsia + NAC 2 $\mu \mathrm{M}$

2. = HUVECs dipapar dengan $2 \%$ plasma eklampsia + NAC 2 $\mu \mathrm{M}+$ Vitamin $\mathrm{C} 100 \mu \mathrm{M}$

3. = HUVECs dipapar dengan $2 \%$ plasma eklampsia + NAC 2 $\mu \mathrm{M}+$ Vitamin $\mathrm{E} 100 \mu \mathrm{M}$

4. = HUVECs dipapar dengan $2 \%$ plasma eklampsia + NAC 2 $\mu \mathrm{M}+$ Vitamin $\mathrm{C} 100 \mu \mathrm{M}+$ Vitamin $\mathrm{E} 100 \mu \mathrm{M}$

Gambar 1 menunjukkan Kadar $\mathrm{H}_{2} \mathrm{O}_{2}$ pada perlakuan 1, 2, 3 dan 4 lebih rendah secara signifikan dibandingkan dengan kontrol positif $(p=0,000)$. Kadar $\mathrm{H}_{2} \mathrm{O}_{2}$ antara perlakuan 2 dengan perlakuan 3 tidak berbeda signifikan ( $p=0,855)$, kadar $\mathrm{H}_{2} \mathrm{O}_{2}$ antara perlakuan 2 dengan perlakuan 4 tidak berbeda signifikan $(p=0,328)$, kadar $\mathrm{H}_{2} \mathrm{O}_{2}$ antara perlakuan 3 dengan perlakuan 4 tidak berbeda signifikan $(p=0,420)$. Kadar $\mathrm{H}_{2} \mathrm{O}_{2}$ antar perlakuan 1, 2, 3 dan 4 tidak berbeda signifikan. Kadar $\mathrm{H}_{2} \mathrm{O}_{2}$ antar perlakuan 1 dengan perlakuan 2, 3 dan 4 tidak berbeda secara signifikan. Kadar $\mathrm{H}_{2} \mathrm{O}_{2}$ antar perlakuan 1 dengan perlakuan 2, 3, dan 4 tidak berbeda secara signifikan.

\section{Kadar MDA pada Sel Endotel HUVECs}

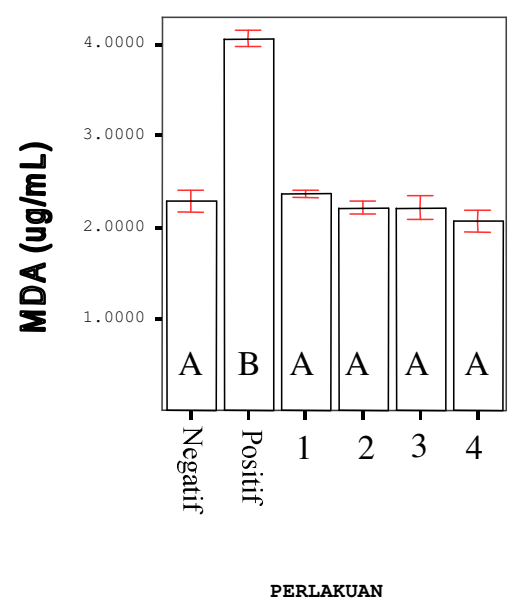

\section{Gambar 2. Grafik Kadar rata-rata dan SE MDA kultur HUVECs pada semua kelompok}

Keterangan : ${ }^{*}=$ signifikan $(p<0.05)$

Notasi yang berbeda menunjukkan perbedaan yang signifikan.

- = HUVECs dipapar dengan $2 \%$ plasma kehamilan normal

$+=$ HUVECs dipapar dengan $2 \%$ plasma eklampsia

1. = HUVECs dipapar dengan $2 \%$ plasma eklampsia + NAC 2 $\mu \mathrm{M}$

2. = HUVECs dipapar dengan $2 \%$ plasma eklampsia + NAC 2 $\mu \mathrm{M}+$ Vitamin $\mathrm{C} 100 \mu \mathrm{M}$

3. = HUVECs dipapar dengan $2 \%$ plasma eklampsia + NAC 2 $\mu \mathrm{M}+$ Vitamin $\mathrm{E} 100 \mu \mathrm{M}$

4. = HUVECs dipapar dengan $2 \%$ plasma eklampsia + NAC 2 $\mu \mathrm{M}+$ Vitamin C $100 \mu \mathrm{M}+$ Vitamin E $100 \mu \mathrm{M}$

Gambar 2 menunjukkan bahwa kadar MDA antara perlakuan 1, dan perlakuan 3 dibandingkan dengan kontrol positif berbeda signifikan $(p=0.000)$. Kadar MDA antara perlakuan 4 dibandingkan dengan kontrol positif signifikan $(p=0.000)$, kadar MDA antara perlakuan 2 dibandingkan dengan perlakuan 3 tidak berbeda signifikan $(p=1,000)$, kadar MDA antara perlakuan 2 dibandingkan dengan perlakuan 4 tidak berbeda signifikan $(p=0,594)$, kadar MDA antara perlakuan 3 dengan perlakuan 4 tidak berbeda signifikan $(p=0,594)$. Kadar MDA antara perlakuan 1 dengan perlakuan 2,3 dan 4 tidak berbeda signifikan 


\section{Kadar NO pada Media HUVECs}

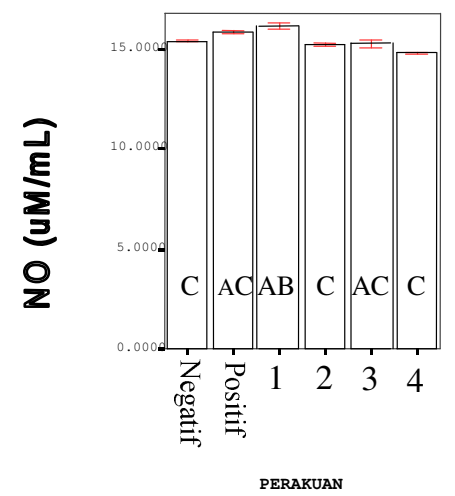

\section{Gambar 3. Grafik Kadar rata-rata dan SE NO pada kultur sel endotel HUVECs.}

Keterangan : * $=$ signifikan $(p<0.05)$

Notasi yang berbeda menunjukkan perbedaan yang signifikan.

- = HUVECs dipapar dengan $2 \%$ plasma kehamilan normal

$+=$ HUVECs dipapar dengan $2 \%$ plasma eklampsia

1. = HUVECs dipapar dengan $2 \%$ plasma eklampsia + NAC 2 $\mu \mathrm{M}$

2. = HUVECs dipapar dengan $2 \%$ plasma eklampsia + NAC 2 $\mu \mathrm{M}+$ Vitamin C $100 \mu \mathrm{M}$

3. = HUVECs dipapar dengan $2 \%$ plasma eklampsia + NAC 2 $\mu \mathrm{M}+$ Vitamin $\mathrm{E} 100 \mu \mathrm{M}$

4. = HUVECs dipapar dengan $2 \%$ plasma eklampsia + NAC 2 $\mu \mathrm{M}+$ Vitamin C $100 \mu \mathrm{M}+$ Vitamin E $100 \mu \mathrm{M}$

Gambar 3 menunjukkan bahwa tidak ada perbedaan signifikan anatara perlakuan 1 dan 3 dengan kontrol positif. Sebaliknya kadar NO lebih rendah secara signifikan pada perlakuan $2(p=0,044)$ dan $4(p=0,006)$ dibandingkan kontrol positif. Apabila dibandingkan dengan perlakuan 1 , kadar NO pada perlakuan $2(p=0,006), 3$ $(0,008)$ dan $4(p=0,001)$ lebih rendah secara signifikan. Tidak ada perbedaan signifikan antara kadar NO pada perlakuan 2 dengan perlakuan $3(p=0,881)$ dan $4(p=0,150)$ juga antara perlakuan 3 dan $4(p=0,117)$

\section{Kadar GSH/GSSG pada Media HUVECs}

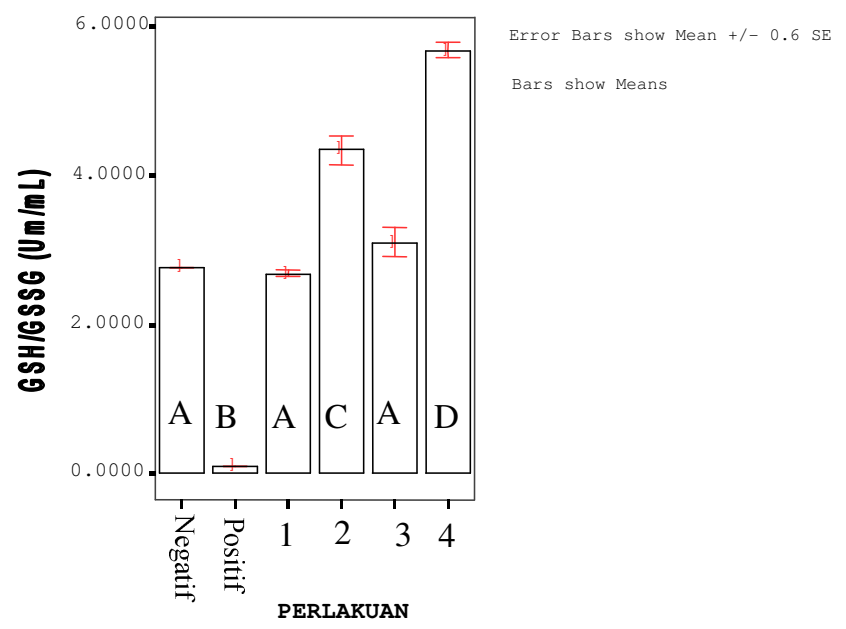

\section{Gambar 4. Grafik Kadar rata-rata dan se GSH/GSSG pada kultur sel endotel HUVECs.}

Keterangan : ${ }^{*}=$ signifikan $(p<0.05)$

Notasi yang berbeda menunjukkan perbedaan yang signifikan.

- = HUVECs dipapar dengan $2 \%$ plasma kehamilan normal

$+=$ HUVECs dipapar dengan $2 \%$ plasma eklampsia

1. = HUVECs dipapar dengan $2 \%$ plasma eklampsia + NAC 2 $\mu \mathrm{M}$

2. = HUVECs dipapar dengan $2 \%$ plasma eklampsia + NAC 2 $\mu \mathrm{M}+$ Vitamin C $100 \mu \mathrm{M}$

3. = HUVECs dipapar dengan $2 \%$ plasma eklampsia + NAC 2 $\mu \mathrm{M}+$ Vitamin $\mathrm{E} 100 \mu \mathrm{M}$

4. = HUVECs dipapar dengan $2 \%$ plasma eklampsia + NAC 2 $\mu \mathrm{M}+$ Vitamin $\mathrm{C} 100 \mu \mathrm{M}+$ Vitamin $\mathrm{E} 100 \mu \mathrm{M}$

Gambar 4 menunjukkan bahwa rata-rata kadar rasio GSH/GSSG signifikan lebih tinggi pada perlakuan 2 dibandingkan dengan kontrol positif $(p=0.000)$, kadar GSH/GSSG signifikan lebih tinggi pada perlakuan 3 dibandingkan dengan kontrol positif $(p=0.000)$, kadar GSH/GSSG signifikan lebih tinggi pada perlakuan 4 dibandingkan dengan kontrol positif $(p=0.000)$, kadar rasio GSH/GSSG signifikan lebih tinggi pada perlakuan 2 dibandingkan dengan perlakuan $1 \quad(p=0.000)$, kadar GSH/GSSG tidak berbeda signifikan antara perlakuan 3 dibandingkan dengan perlakuan $1 \quad(p=0.188)$, kadar GSH/GSSG signifikan lebih tinggi pada perlakuan 4 dibandingkan dengan perlakuan $1 \quad(p=0.000)$, kadar GSH/GSSG signifikan lebih tinggi pada perlakuan 2 dibandingkan dengan perlakuan $3 \quad(p=0.002)$, kadar GSH/GSSG signifikan lebih tinggi pada perlakuan 4 dibandingkan dengan perlakuan 2 ( $p=0,001)$, kadar GSH/GSSG signifikan lebih tinggi pada perlakuan 4 dibandingkan dengan perlakuan $3(p=0.000)$. 


\section{Sel Endotel (HUVECs) yang Dipapar 2\% Plasma Eclapmsia}

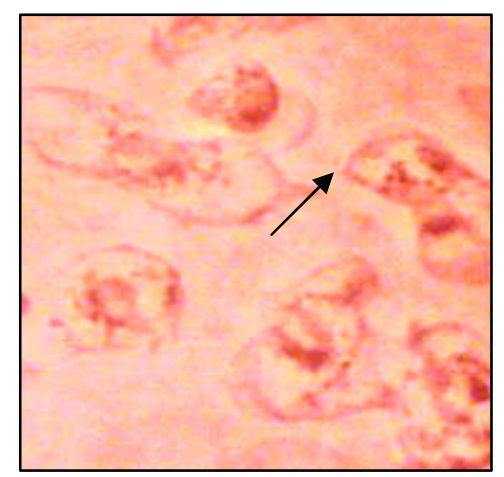

Gambar 5: Kultur HUVECs yang dipapar 2\% plasma Eclampsia dengan pembesaran 1000x.

Keterangan: Tanda panah menunjukkan bentuk selnya tidak normal, sel mengalami shrinkage dan tampak adanya vacuola yang menunjukkan sel mengalami apoptosis.

\section{Sel Endotel (HUVECs) yang Dipapar 2\% Plasma Eclampsia + NAC $2 \mu \mathrm{M}$ + Vitamin C $100 \mu \mathrm{M}$ dan Vitamin E $100 \mu \mathrm{M}$}

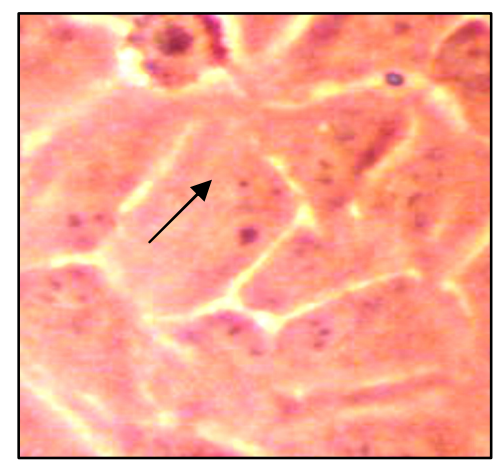

Gambar 6: Kultur (HUVECs) yang dipapar 2\% Plasma Eclampsia + NAC $2 \mu \mathrm{M}+$ Vitamin C $100 \mu \mathrm{M}$ dan Vitamin $\mathrm{E} 100 \mu \mathrm{M}$ dengan pembesaran 1000x.

Keterangan:Tanda panah menunjukkan bentuk sel normal, kontak antar sel tampak jelas.

\section{DISKUSI}

Pada preeklampsia terjadi stress oksidatif ditandai dengan meningkatnya lipid peroksida dan menurunnya kadar antioksidan. Antioksidan dalam diet dari tumbuhan melindungi terhadap penyakit yang berhubungan dengan stress oksidatif, namun hasil dari percobaan intervensi dengan singgle vitamin $\mathrm{E}$ atau $\mathrm{C}$ atau ß-carotene tidak mempunyai pengaruh perlindungan seperti perlindungan antioksidan dari diet $(18,19)$. Pada penelitian pemberian antioksidan ß-carotene telah menghasilkan efek samping yang merugikan dalam percobaan klinis. Satu alasan tidak efektifnya dari percobaan klinis adalah bahwa perlindungan dari buah2-an dan sayuran merupakan hasil dari kerja sama senyawa antioksidan yang ada dimakanan. Antioksidan dalam bekerjanya merupakan suatu network. (20).

Pada perlakuan 2, kadar $\mathrm{H}_{2} \mathrm{O}_{2}$ dan lipid peroksida lebih rendah dari perlakuan 1 meskipun tidak signifikan. Hal ini dapat dijelaskan bahwa pada perlakuan 2, antioksidan NAC $2 \mu \mathrm{M}$ sebagai prekursor terbentuknya GSH, GSH yang terbentuk dapat memungut radikal $\mathrm{H}_{2} \mathrm{O}_{2}$ dan lipid peroksida, sedangkan radikal GS• akan dipungut oleh vitamin $\mathrm{C}$ kembali ke bentuk GSH yang dapat dilihat dari peningkatan kadar rasio GSH/GSSG. GSH juga dapat mendonorkan atom $\mathrm{H}^{+}$-nya untuk memungut radikal vitamin C. Disamping itu vitamin $\mathrm{C}$ juga dapat memungut oksidan $\mathrm{H}_{2} \mathrm{O}_{2}$ dan lipid peroksida. Kombinasi $\mathrm{NAC} 2 \mu \mathrm{M}+$ Vitamin C $100 \mu \mathrm{M}$ saling bekerja sama dalam memungut radikal bebas, sehingga dapat lebih menurunkan radikal bebas dari pada hanya menggunakan NAC $2 \mu \mathrm{M}$.

Kadar $\mathrm{H}_{2} \mathrm{O}_{2}$ dan lipid peroksida pada kombinasi NAC $2 \mu \mathrm{M}+$ Vitamin E $100 \mu \mathrm{M}$ lebih rendah meskipun tidak signifikan dari pada hanya NAC $2 \mu \mathrm{M}$. Hal ini dapat dijelaskan bahwa GSH yang terbentuk dari pemberian NAC $2 \mu \mathrm{M}$ dapat memungut radikal $\mathrm{H}_{2} \mathrm{O}_{2}$ dan lipid peroksida, sedangkan radikal GS• akan dipungut oleh vitamin $\mathrm{E}$ kembali ke bentuk GSH yang dapat dilihat dari peningkatan kadar rasio GSH/GSSG. GSH juga dapat mendonorkan atom $\mathrm{H}^{+}$-nya untuk memungut radikal vitamin $\mathrm{E}$. Disamping itu vitamin $\mathrm{E}$ juga dapat memungut radikal $\mathrm{H}_{2} \mathrm{O}_{2}$ dan lipid peroksida. Kombinasi NAC $2 \mu \mathrm{M}+$ Vitamin E $100 \mu \mathrm{M}$ saling bekerja sama dalam memungut radikal bebas, sehingga dapat lebih menurunkan radikal bebas dari pada hanya menggunakan NAC $2 \mu \mathrm{M}$.

Vitamin C adalah antioksidan yang bisa menghentikan propagasi dari proses peroksidasi dengan cara mendonorkan atom $\mathrm{H}^{+}$-nya. Vitamin $\mathrm{C}$ juga membantu mengembalikan vitamin $\mathrm{E}$ dan $\mathrm{GSH}$ yang teroksidasi menjadi GSH bukan radikal. Pada percobaan randomisasi pemberian dengan suplementasi vitamin $E$ dan $C$ untuk pencegahan $P E$ tidak memberikan manfaat (21). Pemberian vitamin $\mathrm{E}$ dan $\mathrm{C}$ menurunkan stress oxidatif bila diberikan pada awal kehamilan, menghasilkan lebih rendah kejadian Preeklampsia (13).

Pada kombinasi NAC $2 \mu \mathrm{M}+$ Vitamin C $100 \mu \mathrm{M}+$ Vitamin $\mathrm{E} 100 \mu \mathrm{M}$, kadar radikal $\mathrm{H}_{2} \mathrm{O}_{2}$ dan lipid peroksida lebih rendah dari pada hanya diberi 1 atau 2 kombinasi, begitu juga dari kadar rasio GSH/GSSG paling tinggi dengan 3 kombinasi antioksidan. Keadaan ini dapat diterangkan bahwa ke 3 antioksidan ini saling sinergis dalam memungut radikal bebas. Glutathione, vitamin $\mathrm{C}$ dan vitamin $\mathrm{E}$ mendonorkan atom $\mathrm{H}^{+}$-nya pada waktu memungut radikal bebas $\mathrm{H}_{2} \mathrm{O}_{2}$ dan lipid peroksida akan terbentuk radikal GS•, vitamin $\mathrm{C}$ dan vitamin $\mathrm{E}$. Vitamin $\mathrm{C}$ dan vitamin $\mathrm{E}$ dapat mendonorkan atom $\mathrm{H}^{+}$-nya untuk memungut radikal GS • mengembalikan ke bentuk GSH. Glutathione dapat mengembalikan radikal vitamin $\mathrm{C}$ dan 
radikal vitamin $\mathrm{E}$ kembali ke bentuk vitamin $\mathrm{C}$ dan vitamin $\mathrm{E}$ bukan radikal. Vitamin $\mathrm{C}$ dapat mendonorkan atom $\mathrm{H}^{+}$-nya pada waktu memungut radikal vitamin $\mathrm{E}$. Vitamin $\mathrm{C}$ bisa secara langsung berinteraksi dengan membran plasma memberikan elektron ke radikal vitamin $\mathrm{E}$ dalam aktivitas oksidoreduktase ke trans-plasma membrane (22).

Dengan ke 3 kombinasi antioksidan tersebut, aktivitas antioksidannya lebih efektif dan bisa bekerja lebih lama dalam memungut radikal bebas, sehingga lebih efektif dalam menurunkan stress oxidatif sel endotel HUVECs yang ditimbulkan oleh pemaparan 2\% plasma E. Hal ini dapat dilihat dari viabilitas sel endotel HUVECs lebih baik pada paparan 3 kombinasi antioksidan

Kadar NO pada kombinasi NAC $2 \mu \mathrm{M}+$ Vitamin C $100 \mu \mathrm{M}, \quad \mathrm{NAC} 2 \mu \mathrm{M}+$ Vitamin E $100 \mu \mathrm{M}, \mathrm{NAC} 2 \mu \mathrm{M}+$
Vitamin C $100 \mu \mathrm{M}+$ Vitamin E100 $\mu \mathrm{M}$ lebih rendah secara signifikan dengan hanya diberi NAC $2 \mu \mathrm{M}$. Penurunan kadar NO ini karena sel dalam keadaan seimbang antara oksidan dan antioksidan, sehingga sel endotel tidak terinduksi untuk memproduksi NO lebih tinggi.

\section{KESIMPULAN:}

Tiga kombinasi antioksidan NAC $2 \mu \mathrm{M}+$ Vitamin $\mathrm{C}$ $100 \mu \mathrm{M}+$ Vitamin E $100 \mu \mathrm{M}$ lebih optimal dalam meningkatkan rasio GSH/GSSG.

\section{SARAN:}

Dilakukan uji klinik pemberian kombinasi antioksidan pada penderita Preeklampsia dengan terapi standart yang ada.

\section{DAFTAR KEPUSTAKAAN}

1. Many, A., Hubel, A.C., Fisher, J.S., Roberts, M.J., Zhou, Y. Invasive Cytotrophoblasts Manifest Evidence of Oxidative Stress in Preeclampsia, AM.J. Pathology. 2000; 158: 321-331.

2. Zhou, Y., Damsky, H.C., Fisher, J.S. Preeclampsia Is Associated with Failure of Human Cytotrophoblasts to Mimic a Vascular Adhesion Phenotype. JCl. 1997; 99.9:2152-2184.

3. Cunningham, G.F, Gant, F.N, Leveno, J.K, Larry, C.G, Hauth, C.J, Wenstrom, D.K. Hipertensive Disorder in Pregnancy, Williams Obstetrics. 2 1st. 2001; 587- 809.

4. Candra S, Muliartha, I.K., Suwarto, S., Widodo, A.M. Kadar H2O2 dan Rasio GSH/GSSH pada kultur sel endothel (HUVECs) yang dipapar dengan $2 \%$ plasma kehamilan normal, PEB 2\% dan eklampsia $2 \%$. Pertemuan Ilmiah Tahunan Fetomaternal. Jogja. 2007; March

5. Hung, H.T., Skepper, N.J., Graham, J., Burton, J.G.,. In Vitro Ischemia-Reperfusion Injury in Term Human Placenta as a Model for Oxidative Stress in Pathological Pregnancies, AM.J. Pathology. 2001; 159:1031-1043.

6. Lyall, F., and Greer, A.I. The Vascular Endothelium in Normal Pregnancy and Pre-eclampsia, Revieuw of Reproduction. 1998;1:107-118.

7. Candra S, Muliartha, I.K., Suwarto, S., Widodo, A.M. Gambaran Kadar Vitamin B1, Vitamin C dan Vitamin A dari Asupan Makanan Ibu Kehamilan Normal, PEB dan Eklampsia. Pertemuan Ilmiah Tahunan Obstetri dan Ginekologi ke XV. 2007; Mataram. Juli 11

8. Candra S, Muliartha, I.K., Suwarto, S., Widodo, A.M. Kadar MDA dan Rasio GSH/GSSG pada Kehamilan Normal, Preeklampsia Berat dan Eklampsia di Malang. Jurnal Kedokteran Brawijaya. 2007; 22(1):35-39

9. Wang, J., \& Trudinger, B. Endothelial Cell Dysfunction in Preeclampsia, Journal of Nephrology. 1998; 11(2):53-58.

10. Kharb, S. Vitamin E and C in Preeclampsia, Eur J Obstet Gynecol Reprod Biol. 2000;93(1):37-39.

11. Beinder, E., Scalera, F., Schlembach, D. Influence of Reduced Intracellular Glutathione Availability on the Secretion of Vasoactive Substances by Human Umbilical Vein Endothelial Cells, Hypertens Pregnancy. 2001; 20(1):45-58.

12. Chaudiere, J., lliou, F.R. Intracellular Antioxidants: From Chemical to Biochemical Mechanisms, Food Chem Toxicol. 1999; 37: (9-10): 949-82

13. Chappell, L.C, Seed, P.T, Briley, A.L, et al. Effect of Antioxidants on the Occurrence of Pre-eclampsia in Women at Increased Risk: a Randomised Trial, Lancet. 1999; 4;354:810-6.

14. Purro S.A. et al. Hydrogen Peroxide (H2O2) Levels were Assayed in the Culture Media. Journal Neurochemistry; 103(1): 141-144.

15. Das, U.N,Elis, G,Begin, M.E, Horrobin, D.F. Free Radical Bio. Med. 1987; 3:9.

16. Oxford Biomedical Reseach. Colonimetric NO-Enzymatic Assay for Nitric Oxide Product NO.NB 88. Oxford Biomedical Reseach, Inc, USA, 2001.

17. Baker. Micro-Glutathione Assay. Anal. Biochem. 1990; 90:360.

18. Berg, V.D.R., Vliet, V.T., Broekmans, W.M., et al. A Vegetable/fruit Concentrate With High Antioxidant Capacity Has no Effect on Biomarkers of Antioxidant Status in Male Smokers.J Nutr. 2001;131:1714 -1722.

19. Block, G, Norkus, E, Hudes, M, Mandel, S, Helzlsouer, K. Which Plasma Antioxidants are Most Related to Fruit and Vegetable Consumption?Am J Epidemiol. 2001;154:1113-1118. 
20. Bente, L.H., Kari, H., Mari, C.W. M., et al. Nutrient Requirements; Systematic Screening of Total Antioxidants in Dietary Plants,. The American Society for Nutritional Sciences J. Nutr. 2002;132:461-471.

21. Carr, A and Frei, B. Does Vitamin C Act as a Pro-oxidant Under Physiological Conditions? The FASEB Journal. 1999;13:1007-1024.

22. Denisov, T.E., Afanas'ev, B.I. Oxidation and Antioxidants in Organic Chemistry and Biology. 2005;849-891. 
